\title{
Response of Two Maize Hybrids to Spatial Distribution and Nitrogenous Fertilization Rates
}

\author{
Gomaa, M. A., F.I. Radwan, E. E. Kandil and M. A. Emhemmed \\ Plant Production Department, Faculty of Agriculture (Saba Basha), Alexandria \\ University, Alexandria, Egypt
}

\begin{abstract}
To investigate the response of two maize hybrids to spatial distribution and nitrogen fertilization rates. In this respect, two filed experiments were conducted at the Experimental Farm, Faculty of Agriculture (Saba Basha), Alexandria University during 2014 and 2015 seasons in a split- split plot design. Whereas, three factors can be illustrated as follows: the main plot included two maize hybrids (30N11 and 31G98), while, plant spacing (20, 30 and $40 \mathrm{~cm}$ ) was arranged in the sub plots, while nitrogen fertilization (192, 288 and $384 \mathrm{~kg} \mathrm{~N} / \mathrm{ha}$.) allocated in sub- sub plot. The obtained results cleared that maize hybrid $30 \mathrm{~N} 11$ recorded higher plant height $(\mathrm{cm})$, ear weight $(\mathrm{g})$, grain weight/ear $(\mathrm{g})$, number of grains /ear, 1000-grains weight $(\mathrm{g})$, number of rows/ear, grain yield (t/ha), biological yield ( $/ / \mathrm{ha})$, harvest index (\%), grains NPK and protein contents than the other hybrid 31G98 in the first and second seasons, respectively. The highest means values of yield and chemical composition characters were obtained using nitrogen fertilizer at rate of $384 \mathrm{~kg} / \mathrm{ha}$., in both seasons, while the lowest ones were recorded by application of nitrogen at $192 \mathrm{~kg} / \mathrm{ha}$., in both seasons. Wider spacing between plants $(40 \mathrm{~cm})$ produced the higher yield and its components and protein content and NPK in the two successive seasons than narrower spacing $(20 \mathrm{~cm})$ which produced the lowest mean values of these characters.
\end{abstract}

Key words: maize; hybrids; spatial distribution; nitrogen rates; yield; chemical composition

\section{INTRODUCTION}

Maize (Zea mays L.) is the third most important staple food crop in terms of area and production after wheat and rice in Egypt. Also, in the world, it is one of the important cereal crops in the world after wheat and rice (Gerpacio and Pingali, 2007).

Improved cultural practices can play an important role in augmenting yield of corn crop. For an optimal yield, the nitrogen supply must be available according to the needs of the plant. On the other hand, suitable plants spacing for optimum leaf growth by controlling water, fertilizer and chemical inputs is essential for improving the growth variables responsible for high yield. Optimum plant densities ensure the plants to grow in their aerial and underground parts through different utilization of solar radiation and nutrients. When the plant density exceeds an optimum level, competition among plants for light above ground or for nutrients below the ground become severe, consequently the plant growth slows down and the grain yield decreases (Hasanuzzaman et al., 2009). Plant population is an improtant factor which affects the crop yield. Yield was increased by $4 \%$ with increasing plant density (Shapiro and Wortmann, 2006). Higher plant population produce $25 \%$ more grain yield and $38 \%$ more biomass as compared with low plant population and early sown crop produce $19 \%$ more grain yield and $11 \%$ more biomass than late planted crop (Abdul et al., 2007).

Maximum crop production can be achieved by development of improved crop hybrids and suitable growing environment and soil with optimum plant 
population/ha. Optimum plant population is the prerequisite for obtaining maximum yield (Trenton et al., 2006 and Gustavo et al., 2006).

Hybrids exhibited such variations in their yield attributes as cob length (cm), number of row/cob, number of kernels/row, number of kernels/cob, 100kernel weight (g), stover yield Mg/ha., grain yield Mg/ha, biological yield ton/ha., and harvest index (\%), and protein \%. However, plant population 64000 plant/ha., gave the highest mean values for most studied characters and protein $\%$. , and reduced weeds spread. Also, hybrid "TWC 352" recorded the highest values of most studied parameters under Alexandria conditions (Kandil, 2014).

Nitrogen is a key factor for plant photosynthesis, ecosystem productivity and leaf respiration (Johnson, 2001 and Martin et al., 2008). Nitrogen stress may affect the light use efficiency and consequently influence long-term changes in vegetation biomass and carbon sequestration (Peng et al., 2012). Increase nitrogen fertilization levels upto $200 \mathrm{~kg} \mathrm{ha}^{-1}$ enhanced the plant height, grain yield and straw yield of hybrid maize, whereas increasing nitrogen levels decreased the harvest, grain, and straw ratio (Dawadi and Sah, 2012). The lowest ear weight was related to the lowest nitrogen level, while the highest ear weight was observed by the highest nitrogen level (240 $\left.\mathrm{kg} \mathrm{N} \mathrm{ha}^{-1}\right)$, while there was no significant difference among nitrogen levels was observed on harvest index (Hoshang, 2012). Nitrogen fertilization levels, maize hybrids and their interactions showed such significant effects on maize growth, crop yield and its components. The maximum plant height, leaf area index (LAI), chlorophyll SPAD unit, number of rows/cob, number of kernels/row, number of kernels cob, 1000 grain weight, stover, grain, biological yields, harvest index and protein content were produced by the application either 429 or $357 \mathrm{~kg} \mathrm{~N} / \mathrm{ha}$ (Kandil, 2013). There were gradual and significant increases in all growth parameters and grain yield resulted from foliar spray by raising $\mathrm{N}$ - fertilizer upto $288 \mathrm{~kg}$ $\mathrm{N} /$ ha., in both seasons. The S.C Pioneer $30 \mathrm{~K} 09$ maize hybrid treated with 288 $\mathrm{N} / \mathrm{ha}$., produced the maximum values of plant height and grain yield in both seasons (Faheed et al., 2016).

Keeping in view the importance of plant density and nitrogen fertilization, the study was conducted to find out optimum plant spacing and suitable nitrogen fertilization level for getting higher yield of maize hybrid.

\section{MATERIALS AND METHODS}

The present study was carried out at the Experimental Farm, Faculty of Agriculture (Saba- Basha), Alexandria University, Egypt, during the two successive growth summer seasons of 2014 and 2015, to study the response of two maize hybrids to spatial distribution and nitrogen fertilization rates in a splitsplit plot design. Whereas, three factors can be illustrated as follows: the main plot included two maize hybrids (30N11 and 31G98), while plant spacing (20, 30 and $40 \mathrm{~cm}$ ) was arranged in the sub plots, while nitrogen fertilization $(192,288$ and $384 \mathrm{~kg} \mathrm{~N} / \mathrm{ha}$.) allocated in sub- sub plot. 
The grains of the tested two hybrids (31G98 and 30N11) were obtained from Maize Research Section Agriculture Research Center, Ministry of Agriculture. The grains were sown on May $8^{\text {th }}$ and $10^{\text {th }} 2014$ and 2015 seasons, respectively.

Soil texture was clay loam. A surface sample $(0-30 \mathrm{~cm})$ was collected before planting to identify some physical and chemical properties of this soil, as shown in Table (1) according to Page et al. (1982) and Klute (1986). The preceding crop was Egyptian clover (berseem) in the first season and barley (Hordium vulgare, L.) in the second season, respectively.

Each sub sub plot size was $12.60 \mathrm{~m}^{2}$ included 6 ridges each $3 \mathrm{~m}$ in length and $0.70 \mathrm{~m}$ in width with the distance between hills as the above treatments mentioned.

Phosphorus fertilizer was added at rate of $100 \mathrm{~kg}$ calcium super phosphate $\left(15.5 \% \mathrm{P}_{2} \mathrm{O}_{5}\right)$ just before sowing. Mineral nitrogen fertilizer was fully given the dose in a form of urea $(46 \% \mathrm{~N})$ after thinning before the first irrigation and before the second irrigation.

Table (1).Some Physical and chemical properties of the experimental soil in 2014 and 2015 seasons.

\begin{tabular}{|c|c|c|}
\hline \multicolumn{3}{|c|}{ Soil properties } \\
\hline & \multicolumn{2}{|c|}{ Season } \\
\hline & 2014 & 2015 \\
\hline \multicolumn{3}{|l|}{ A) Mechanical analysis : } \\
\hline Clay \% & 38 & 37 \\
\hline Sand \% & 32 & 33 \\
\hline Silt \% & 30 & 30 \\
\hline Soil texture & \multicolumn{2}{|c|}{ Clay loam soil } \\
\hline \multicolumn{3}{|l|}{ B) Chemical properties } \\
\hline $\mathrm{pH}(1: 1)$ & 8.20 & 8.31 \\
\hline E.C. $(\mathrm{dS} / \mathrm{m})(1: 2)$ & 3.80 & 3.70 \\
\hline \multicolumn{3}{|c|}{ 1) Soluble cations (1:2) (cmol/kg soil) } \\
\hline $\mathrm{K}^{+}$ & 1.52 & 1.54 \\
\hline $\mathrm{Ca}^{++}$ & 9.4 & 8.7 \\
\hline $\mathrm{Mg}^{++}$ & 18.3 & 18.5 \\
\hline $\mathrm{Na}^{++}$ & 13.50 & 13.8 \\
\hline \multicolumn{3}{|c|}{ 2) Soluble anions (1:2) (cmol/kg soil) } \\
\hline $\mathrm{CO}_{3}^{--}+\mathrm{HCO}_{3}^{-}$ & 2.90 & 2.80 \\
\hline $\mathrm{Cl}^{-}$ & 20.4 & 19.80 \\
\hline $\mathrm{SO}_{4}^{-}$ & 12.50 & 12.60 \\
\hline Calcium carbonate (\%) & 6.50 & 7.00 \\
\hline Total nitrogen \% & 1.00 & 0.91 \\
\hline Available phosphate $(\mathrm{mg} / \mathrm{kg})$ & 3.70 & 3.55 \\
\hline Organic matter (\%) & 1.41 & 1.40 \\
\hline
\end{tabular}


Grain yield and yield components as cob length $(\mathrm{cm})$, number of rows $\mathrm{cob}^{-1}$, number of kernels row ${ }^{-1}$, number of kernels $\mathrm{cob}^{-1}, 100$ - kernel weight $(\mathrm{g})$, stover yield ton ha ${ }^{-1}$, grain yield ton ha-1, biological yield (ton ha ${ }^{-1}$ ) harvest index $(\mathrm{H} . \mathrm{I} . \%)$ are measurements were obtained as an average of 2 ridges from mid of each plot.

Protein percentage was determined by estimating the total nitrogen in the grains and multiplied by 6.25 to obtain the percentage according of grains protein percentage to A.O. A.C. (1990). NPK percentages were determined in the dry grains. Their dry weights were determined following drying in a drying chamber to a constant weight at $75^{\circ} \mathrm{C}$ for 72 hour according to Tandon (1995). After dryness, the plant samples were milled and stored for analysis as reported. However, $0.5 \mathrm{~g}$ of the grains powder was wet-digested with $\mathrm{H}_{2} \mathrm{SO}_{4}-$ $\mathrm{H}_{2} \mathrm{O}_{2}$ mixture according to (Lowther, 1980) and the following determinations were carried out in the digested solution to determine NPK. Total nitrogen was determined in digested plant material colorimetrically by Nessler's method (Chapman and Pratt, 1978). Phosphorus was determined by the Vanadomolyate yellow method as given by Jackson (1973) and the intensity of colour developed was read in spectrophotometer at $405 \mathrm{~nm}$. Potassium was determined according to the method described by method Jackson (1973) using Beckman Flame photometer.

Data obtained was exposed to the proper method of statistical analysis of variance as described by Gomez and Gomez (1984). The treatments means were compared using the least significant differences (L.S.D.) test at $5 \%$ level probability by using the split- split model as obtained by CoStat $6.311(2005)$ as statistical program.

\section{RESULTS AND DISCUSSIONS}

Results recorded in Tables (2 and 3) revealed that plant height (cm), ear weight (g), grain weight/ear (g), number of grains/ear, 100-grains weight $(\mathrm{g})$, number of rows/ear, grain yield (t/ha), biological yield (ton/ha) and harvest index (\%) of two maize hybrids were, significantly, affected by plant spacing and nitrogen fertilizer rates in both seasons.

Results presented in the same tables demonstrated that maize hybrid "30N11" had higher value for the yield and its components i.e. plant height $(\mathrm{cm})$, ear weight (g), grain weight/ear (g), number of grains /ear, 100- grains weight (g), number of rows/ear, grain yield (t/ha), biological yield (ton/ha) and harvest index (\%) than the other hybrid "31G98" in the first and second seasons, respectively. The difference may be attributed to genetically differences between two maize hybrids which play an important role for make up the available nutrients and yield for the maize hybrids. These findings are in harmony with those obtained by Kandil (2014). 
Results, also demonstrated that spacing between hills $(40 \mathrm{~cm})$, significantly, increased the yield and its components than narrower spacing (20 $\mathrm{cm})$. These results are in agreement with those reported by Ahmad et al. (2010), Saadat et al. (2010), Peykarestan and Seif (2012), Moosavi et al. (2012), Lyocks et al. (2013) and Kandil (2014) who showed that there was a significant difference among plants spacing on maize characters.

On the other side, results presented in Tables (2 and 3) revealed that increasing nitrogen fertilizer level up to $384 \mathrm{~kg} / \mathrm{ha}$., significantly, increased plant height $(\mathrm{cm})$, and yield components of maize i.e. ear weight $(\mathrm{g})$, grain weight/ear (g), number of grains /ear, 100- grains weight (g), number of rows/ear, grain yield (t/ha), biological yield (t/ha) and harvest index (\%) than application of 192 $\mathrm{kg} \mathrm{N} / \mathrm{ha}$. It can be noticed generally that grain yield and its components affected by nitrogen fertilizer which play an important role in plant growth and finally appeard in gigher grain yield for two hybrids of maize. These finding were consistent with those obtained by Kumar (2008), Khan et al. (2012), Moraditochaec et al. (2012), Nemati and Sharifi (2012) and Kandil (2013).

The interaction between maize hybrids and plant and plant spacing reveal that the highest mean values of straw, and biological yield and harvest index were obtained with $30 \mathrm{~N} 11$ hybrid at $40 \mathrm{~cm}$. In the contrast, growing $31 \mathrm{G} 98$ at $20 \mathrm{~cm}$ produced the lowest ones during two cropping seasons (Table 4).

With regard to maize hybrids $x$ nitrogen level interaction, results in Table (5) showed that the maize hybrid "30N11hybrid" with $288 \mathrm{~kg} \mathrm{~N} / \mathrm{ha}$., recoded the highest mean value of grain yield in the second season.

Considering interaction among maize hybrids $x$ spacing $x$ nitrogen fertilization level were significant for yield and its components characters in both seasons as cleared in Table (6). However, results revealed that wider spacing of "30N11" hybrid plants at $(40 \mathrm{~cm})$ and fertilized with $384 \mathrm{~kg} \mathrm{~N} / \mathrm{ha}$., produced the highest mean value of grain and straw and biological yield in the two respective seasons. 
Table (2). Plant height, yield and its components as affected by two maize hybrids, plant spacing and nitrogen fertilizer rates in 2014 and 2015 seasons.

\begin{tabular}{|c|c|c|c|c|c|c|c|c|c|c|}
\hline \multirow{3}{*}{ Treatments } & \multicolumn{2}{|c|}{ Plant height (cm) } & \multicolumn{2}{|c|}{ Ear weight (g) } & \multicolumn{2}{|c|}{$\begin{array}{c}\text { Grain weight/ear } \\
\text { (g) }\end{array}$} & \multicolumn{2}{|c|}{$\begin{array}{c}\text { Number of grains } \\
\text { /ear }\end{array}$} & \multicolumn{2}{|c|}{$\begin{array}{l}\text { 100-grain } \\
\text { weight (g) }\end{array}$} \\
\hline & \multicolumn{10}{|c|}{ Season } \\
\hline & 2014 & 2015 & 2014 & 2015 & 2014 & 2015 & 2014 & 2015 & 2014 & 2015 \\
\hline \multicolumn{11}{|c|}{ Maize hybrids (H) } \\
\hline 31G98 & $210.59 b$ & $211.30 b$ & $225.12 b$ & $224.43 b$ & $170.86 \mathrm{~b}$ & $172.91 b$ & $511.81 b$ & $518.11 b$ & $39.79 b$ & $40.37 b$ \\
\hline $30 N 11$ & 217.33a & $219.18 a$ & $286.07 a$ & 293.90a & $223.88 a$ & $227.32 a$ & $556.07 a$ & $564.44 a$ & $47.09 a$ & $47.56 a$ \\
\hline LSD at 0.05 & 0.84 & 1.50 & 26.13 & 0.61 & 0.65 & 1.62 & 2.29 & 5.38 & 0.20 & 0.25 \\
\hline \multicolumn{11}{|c|}{ Plant spacing (cm): (S) } \\
\hline 20 & $209.11 c$ & $210.40 c$ & $225.91 c$ & $222.57 c$ & $166.54 c$ & $168.35 c$ & $507.33 c$ & $515.94 c$ & $40.55 c$ & $40.94 c$ \\
\hline 30 & 214.66b & $216.40 b$ & 249.36b & $254.63 b$ & 189.63b & $192.44 b$ & $526.55 b$ & $532.72 b$ & 43.97b & $44.63 b$ \\
\hline 40 & $218.11 \mathrm{a}$ & $218.94 a$ & $291.51 \mathrm{a}$ & $300.29 a$ & $235.94 a$ & $239.55 a$ & $567.94 a$ & $575.16 a$ & $45.81 \mathrm{a}$ & $46.33 a$ \\
\hline LSD at 0.05 & 1.85 & 1.28 & 13.53 & 0.75 & 2.10 & 0.72 & 4.21 & 3.99 & 0.21 & 0.20 \\
\hline \multicolumn{11}{|c|}{$\mathrm{N}$ - fertilizer levels (kg/ha.) } \\
\hline 92 & $209.88 c$ & $207.78 c$ & $222.49 c$ & $214.39 c$ & $163.83 c$ & $165.69 c$ & $446.27 c$ & $451.16 \mathrm{c}$ & $40.46 c$ & $41.02 c$ \\
\hline 288 & $211.94 b$ & $215.92 b$ & $258.66 b$ & $267.46 \mathrm{~b}$ & 196.37b & 198.67b & $524.33 b$ & $533.83 b$ & $43.43 b$ & $43.96 b$ \\
\hline 384 & $220.05 a$ & $222.03 a$ & $285.64 a$ & $295.64 a$ & $231.92 a$ & $235.99 a$ & $631.22 \mathrm{a}$ & $638.83 a$ & $46.45 a$ & $46.91 a$ \\
\hline LSD at 0.05 & 1.49 & 1.20 & 18.87 & 0.64 & 2.00 & 0.74 & 3.71 & 3.71 & 0.64 & 0.24 \\
\hline \multicolumn{11}{|c|}{ Interaction } \\
\hline $\mathrm{H} \times \mathrm{S}$ & * & * & * & * & $\star$ & * & * & * & * & * \\
\hline $\mathrm{H} \times \mathrm{N}$ & * & * & * & * & * & * & * & * & * & * \\
\hline$S \times N$ & * & ns & * & * & * & * & * & * & * & * \\
\hline $\mathrm{H} \times \mathrm{S} \times \mathrm{N}$ & * & $*$ & ns & * & * & * & * & * & * & * \\
\hline
\end{tabular}


Table (3). Yield and its components as affected by two maize hybrids, plant spacing and nitrogen fertilizer rates in 2014 and 2015 seasons.

\begin{tabular}{|c|c|c|c|c|c|c|c|c|c|c|}
\hline \multirow[t]{2}{*}{ Treatment } & \multicolumn{2}{|c|}{$\begin{array}{l}\text { Number of } \\
\text { rows/ear }\end{array}$} & \multicolumn{2}{|c|}{$\begin{array}{l}\text { Straw yield } \\
\text { (ton/ha) }\end{array}$} & \multicolumn{2}{|c|}{$\begin{array}{l}\text { Grain yield } \\
\text { (ton/ha) }\end{array}$} & \multicolumn{2}{|c|}{$\begin{array}{l}\text { Biological yield } \\
\text { (ton/ha) }\end{array}$} & \multicolumn{2}{|c|}{$\begin{array}{c}\text { Harvest index } \\
(\%)\end{array}$} \\
\hline & 2014 & 2015 & 2014 & 2015 & 2014 & 2015 & 2014 & 2015 & 2014 & 2015 \\
\hline \multicolumn{11}{|c|}{ Maize hybrids $(\mathbf{H})$} \\
\hline 31G98 & $13.47 b$ & $13.70 b$ & $9.46 \mathrm{~b}$ & $9.49 b$ & $6.39 \mathrm{~b}$ & $7.08 b$ & $15.86 b$ & $16.57 b$ & $40.20 a$ & $42.62 a$ \\
\hline $30 N 11$ & $14.41 \mathrm{a}$ & $14.58 a$ & $11.43 a$ & $11.47 a$ & $7.69 \mathrm{a}$ & $8.32 a$ & $19.12 a$ & $19.80 a$ & $40.12 a$ & $42.00 \mathrm{~b}$ \\
\hline LSD at 0.05 & 0.45 & 0.11 & 0.745 & 0.633 & 0.395 & 0.609 & 1.14 & 1.24 & 0.306 & 0.586 \\
\hline \multicolumn{11}{|c|}{ Plant spacing (cm): (S) } \\
\hline 20 & $13.24 c$ & $13.53 c$ & $9.11 \mathrm{c}$ & $9.04 c$ & $6.37 c$ & $6.91 \mathrm{c}$ & $15.48 c$ & $15.95 \mathrm{c}$ & $41.16 a$ & $43.26 \mathrm{a}$ \\
\hline 30 & $14.04 b$ & $14.19 b$ & $10.65 b$ & 10.67b & $7.08 \mathrm{~b}$ & $7.71 b$ & $17.74 b$ & $18.39 \mathrm{~b}$ & $39.67 a$ & $41.90 \mathrm{~b}$ \\
\hline 40 & $14.54 a$ & $14.70 \mathrm{a}$ & $11.58 a$ & $11.73 a$ & $7.67 \mathrm{a}$ & $8.48 a$ & $19.25 a$ & $20.21 a$ & $39.65 a$ & $41.77 \mathrm{~b}$ \\
\hline LSD at 0.05 & 0.07 & 0.07 & 0.503 & 0.426 & 0.384 & 0.405 & 0.697 & 0.785 & 1.57 & 0.806 \\
\hline \multicolumn{11}{|c|}{$\mathrm{N}$ - fertilizer levels (kg/ha.) } \\
\hline 92 & $13.21 \mathrm{c}$ & $13.45 c$ & $9.66 b$ & $9.71 b$ & $6.17 \mathrm{~b}$ & $6.86 c$ & $15.83 b$ & $16.57 \mathrm{c}$ & $38.81 \mathrm{~b}$ & $41.27 b$ \\
\hline 288 & 13.96b & $14.24 b$ & $10.59 a$ & $10.67 a$ & $7.41 \mathrm{a}$ & $7.78 b$ & $17.99 a$ & $18.46 \mathrm{~b}$ & $41.15 a$ & $42.15 b$ \\
\hline 384 & $14.46 a$ & $14.73 a$ & $11.10 \mathrm{a}$ & $11.06 a$ & $7.55 a$ & $8.47 a$ & $18.65 a$ & $19.52 a$ & $40.51 a$ & $43.52 \mathrm{a}$ \\
\hline LSD at 0.05 & 0.09 & 0.10 & 0.551 & 0.541 & 0.541 & 0.448 & 0.962 & 0.909 & 1.60 & 1.11 \\
\hline \multicolumn{11}{|c|}{ Interaction } \\
\hline $\mathrm{H} \times \mathrm{S}$ & * & * & * & * & n.s. & * & * & * & * & * \\
\hline $\mathrm{H} \times \mathrm{N}$ & * & * & n.s. & n.s. & n.s. & * & n.s. & n.s. & n.s. & * \\
\hline $\mathrm{S} \times \mathrm{N}$ & * & * & n.s. & n.s. & n.s. & n.s. & n.s. & n.s. & * & * \\
\hline $\mathrm{H} \times \mathrm{S} \times \mathrm{N}$ & * & n.s. & n.s. & n.s. & * & * & * & * & * & * \\
\hline
\end{tabular}


Table (4). Interactions between maize hybrids and plant spacing for grain yield (ton/ha.), straw yield and biological yield and H.I \% in 2014 and 2015 seasons.

\begin{tabular}{|c|c|c|c|c|c|c|c|c|}
\hline \multirow{3}{*}{ Hybrid } & \multirow{3}{*}{$\begin{array}{c}\text { Plant } \\
\text { spacing }\end{array}$} & $\begin{array}{c}\text { Grain yield } \\
\text { (ton } / \text { ha) }\end{array}$ & \multicolumn{2}{|c|}{$\begin{array}{l}\text { Straw yield } \\
\text { (ton/ha) }\end{array}$} & \multicolumn{2}{|c|}{$\begin{array}{l}\text { Biological yield } \\
\text { (ton } / \text { ha) }\end{array}$} & \multicolumn{2}{|c|}{$\begin{array}{l}\text { Harvest index } \\
\text { (H.I\%) }\end{array}$} \\
\hline & & \multicolumn{7}{|c|}{ Season } \\
\hline & & 2015 & 2014 & 2015 & 2014 & 2015 & 2014 & 2015 \\
\hline \multirow{3}{*}{$31 \mathrm{G98}$} & 20 & 6.16 & 7.45 & 7.47 & 13.28 & 13.63 & 43.32 & 44.70 \\
\hline & 30 & 6.89 & 9.66 & & 15.98 & 16.40 & 39.12 & 41.64 \\
\hline & 40 & 8.20 & 11.28 & 11.50 & 18.31 & 19.70 & 38.15 & 41.52 \\
\hline \multirow{3}{*}{$30 N 11$} & 20 & 7.66 & 10.77 & 10.61 & 17.69 & 18.28 & 38.99 & 41.82 \\
\hline & 30 & 8.54 & 11.64 & 11.84 & 19.49 & 20.38 & 40.21 & 41.91 \\
\hline & 40 & 8.77 & 11.88 & 11.97 & 20.18 & 20.73 & 41.16 & 42.28 \\
\hline \multicolumn{2}{|c|}{ LSD } & 0.573 & 0.711 & 0.602 & 0.986 & 1.11 & 2.22 & 1.14 \\
\hline
\end{tabular}

Table (5). Interactions between maize hybrids and nitrogen fertilizer levels for grain yield (ton/ha) and H.I \% in 2014 and 2015 seasons.

\begin{tabular}{|c|c|c|c|c|}
\hline \multirow{3}{*}{ Hybrid } & \multirow{3}{*}{ N levels(Kg/ha.) } & Grain yield & \multicolumn{2}{|c|}{ Harvest index (\%) } \\
\hline & & \multicolumn{3}{|c|}{ Season } \\
\hline & & 2015 & 2014 & 2015 \\
\hline \multirow{3}{*}{$31 \mathrm{G98}$} & 192 & 5.95 & 38.11 & 40.71 \\
\hline & 288 & 6.95 & 40.82 & 41.91 \\
\hline & 384 & 8.35 & 41.66 & 45.24 \\
\hline \multirow{3}{*}{$30 N 11$} & 192 & 7.77 & 39.52 & 41.82 \\
\hline & 288 & 8.62 & 41.49 & 42.39 \\
\hline & 384 & 8.59 & 39.36 & 41.80 \\
\hline & SD at 0.05 & 0.634 & 2.26 & 1.56 \\
\hline
\end{tabular}

Table (6). Interactions among maize hybrids, plant spacing, and nitrogen fertilizer levels for grain yield ( $\mathrm{t} / \mathrm{ha}$ ), biological yield and harvest index (HI \%) in 2014 and 2015 seasons.

\begin{tabular}{|c|c|c|c|c|c|c|c|c|}
\hline \multirow{3}{*}{ Hybrids } & \multirow{3}{*}{$\begin{array}{l}\text { Plant } \\
\text { spacing }\end{array}$} & \multirow{3}{*}{$\begin{array}{l}\text { N levels } \\
\text { (kg/ha.) }\end{array}$} & \multicolumn{2}{|c|}{$\begin{array}{l}\text { Grain yield } \\
\text { (ton/ha) }\end{array}$} & \multicolumn{2}{|c|}{$\begin{array}{c}\text { Biological yield } \\
\text { (ton/ha) }\end{array}$} & \multicolumn{2}{|c|}{$\begin{array}{l}\text { Harvest index } \\
(\text { (H.I. \%) }\end{array}$} \\
\hline & & & \multicolumn{6}{|c|}{ Season } \\
\hline & & & 2014 & 2015 & 2014 & 2015 & 2014 & 2015 \\
\hline \multirow{9}{*}{$31 \mathrm{G} 98$} & \multirow{3}{*}{20} & 192 & 4.12 & 4.56 & 10.38 & 11.12 & 39.69 & 41.03 \\
\hline & & 288 & 5.92 & 5.88 & 13.46 & 13.24 & 43.76 & 44.40 \\
\hline & & 384 & 7.44 & 8.04 & 16.00 & 16.52 & 46.50 & 48.67 \\
\hline & \multirow{3}{*}{30} & 192 & 4.66 & 5.50 & 13.11 & 13.83 & 35.51 & 39.75 \\
\hline & & 288 & 6.16 & 6.16 & 16.28 & 15.76 & 37.74 & 39.11 \\
\hline & & 384 & 8.16 & 9.00 & 18.56 & 19.60 & 44.10 & 46.05 \\
\hline & \multirow{3}{*}{40} & 192 & 6.96 & 7.80 & 17.76 & 18.84 & 39.12 & 41.35 \\
\hline & & 288 & 8.13 & 8.80 & 19.85 & 20.84 & 40.95 & 42.22 \\
\hline & & 384 & 6.00 & 8.00 & 17.33 & 19.41 & 34.39 & 40.99 \\
\hline \multirow{9}{*}{$30 N 11$} & \multirow{3}{*}{20} & 192 & 6.14 & 6.70 & 16.09 & 16.46 & 38.04 & 40.99 \\
\hline & & 288 & 7.52 & 8.36 & 18.28 & 19.36 & 40.98 & 43.05 \\
\hline & & 384 & 7.10 & 7.94 & 18.70 & 19.02 & 37.96 & 41.77 \\
\hline & \multirow{3}{*}{30} & 192 & 7.64 & 8.25 & 18.88 & 19.57 & 40.46 & 42.16 \\
\hline & & 288 & 8.48 & 9.12 & 20.60 & 21.48 & 41.17 & 42.46 \\
\hline & & 384 & 7.42 & 8.26 & 19.00 & 20.08 & 39.01 & 41.10 \\
\hline & \multirow{3}{*}{40} & 192 & 7.52 & 8.36 & 18.77 & 19.61 & 40.05 & 42.64 \\
\hline & & 288 & 8.24 & 8.36 & 19.48 & 20.07 & 42.32 & 41.65 \\
\hline & & 384 & 9.16 & 9.58 & 22.29 & 22.52 & 41.11 & 42.54 \\
\hline LSD at 0.05 & & & 1.32 & 1.09 & 2.36 & 2.23 & 3.92 & 2.71 \\
\hline
\end{tabular}


Results recorded in Table (7) revealed that percentage of nitrogen, phosphorus, potassium and protein in maize grains were, significantly, influenced by adding high level of nitrogen.

Maize hybrid $30 \mathrm{~N} 11$ recorded higher grains NPK and protein content than the other hybrid 31G98 in the first and second seasons, respectively.these results can be concluded that the ability to transport enough absorbed nitrogen, phosphorus, and potassium percentages in grains plant. These results agreed with those obtained by Amin et al. (2003) and Atia and Abdel- Azeem (2005).

The highest values of all chemical compositions character were obtained using nitrogen fertilizer at rate $384 \mathrm{~kg} / \mathrm{ha}$., in both seasons, while, the lowest ones was recorded by application nitrogen at $192 \mathrm{~kg} / \mathrm{ha}$., as shown in (Table 7) in both seasons. These results indicate that $\mathrm{N}$ - fertilization rate increased the capacity of plant in absorbing nutrients. These results are in agreement with others results were reported by Martin et al. (2008), El- Gizawy and Salem (2010) and Dawadi and Sah (2012).

Results in Table (7) revealed that wider spacing between plants $(40 \mathrm{~cm})$ produced higher protein content and NPK in the two successive seasons than narrower spacing $(20 \mathrm{~cm})$ that produced the lowest mean values of these characters.

On the other side, increasing nitrogen fertilizer from 192 to $384 \mathrm{~kg} \mathrm{~N} / \mathrm{ha}$., significantly, increased grain NPK and protein contents in 2014 and 2015 seasons as shown in Table (7). These results are in agreement with those obtained by Sahoo and Mahapatra (2004), Oktem and Oktem (2005), Kar et al. (2006), Melkonian et al. (2008), El-Gizawy and Salem (2010) and Tang et al. (2015). 
Table (7). Macronutrients (N, P and K) and protein percentages as affected by maize hybrids, plant spacing and nitrogen fertilizer rates in 2014 and 2015 seasons.

\begin{tabular}{|c|c|c|c|c|c|c|c|c|}
\hline \multirow{3}{*}{ Treatment } & \multicolumn{2}{|c|}{$\mathbf{N}(\%)$} & \multicolumn{2}{|c|}{$\mathbf{P}(\%)$} & \multicolumn{2}{|c|}{ K (\%) } & \multicolumn{2}{|c|}{ Protein (\%) } \\
\hline & \multicolumn{8}{|c|}{ Season } \\
\hline & 2014 & 2015 & 2014 & 2015 & 2014 & 2015 & 2014 & 2015 \\
\hline \multicolumn{9}{|c|}{ Maize hybrids (H) } \\
\hline $31 \mathrm{G} 98$ & $1.27 b$ & $1.34 \mathrm{~b}$ & $0.634 b$ & $0.638 b$ & 1. $67 \mathrm{~b}$ & $1.68 \mathrm{~b}$ & $7.79 b$ & $8.37 \mathrm{~b}$ \\
\hline 30N11 & $1.32 \mathrm{a}$ & $1.36 \mathrm{a}$ & $0.713 a$ & $0.720 \mathrm{a}$ & 1. $86 a$ & $1.90 \mathrm{a}$ & $8.28 a$ & $8.51 \mathrm{a}$ \\
\hline LSD at 0.05 & 0.01 & 0.01 & 0.003 & 0.003 & 0.01 & 0.05 & 0.07 & 0.11 \\
\hline \multicolumn{9}{|c|}{ Plant spacing (cm): (S) } \\
\hline 20 & $1.22 \mathrm{c}$ & $1.28 \mathrm{c}$ & $0.648 \mathrm{c}$ & $0.652 \mathrm{c}$ & $1.60 \mathrm{c}$ & $1.61 \mathrm{c}$ & $7.65 c$ & $8.03 c$ \\
\hline 30 & $1.31 \mathrm{~b}$ & $1.36 \mathrm{~b}$ & $0.673 b$ & $0.681 b$ & $1.74 b$ & $1.76 \mathrm{~b}$ & $8.22 \mathrm{~b}$ & $8.52 b$ \\
\hline 40 & $1.36 \mathrm{a}$ & $1.40 \mathrm{a}$ & $0.699 a$ & $0.704 a$ & $1.95 \mathrm{a}$ & $1.99 \mathrm{a}$ & $8.51 \mathrm{a}$ & $8.78 \mathrm{a}$ \\
\hline LSD at 0.05 & 0.02 & 0.01 & 0.002 & 0.003 & 0.02 & 0.02 & 0.13 & 0.07 \\
\hline \multicolumn{9}{|c|}{$\mathrm{N}$ - fertilizer levels (kg/ha.) } \\
\hline 92 & $1.21 \mathrm{c}$ & $1.25 \mathrm{c}$ & $0.545 \mathrm{c}$ & $0.551 \mathrm{c}$ & $1.57 \mathrm{c}$ & $1.58 \mathrm{c}$ & $7.57 \mathrm{c}$ & $7.82 \mathrm{c}$ \\
\hline 288 & $1.30 \mathrm{~b}$ & $1.35 \mathrm{~b}$ & $0.682 b$ & $0.685 b$ & $1.76 \mathrm{~b}$ & $1.80 \mathrm{~b}$ & $8.14 b$ & $8.46 b$ \\
\hline 384 & $1.38 \mathrm{a}$ & $1.44 a$ & $0.793 a$ & $0.800 a$ & $1.96 \mathrm{a}$ & $1.99 a$ & $8.67 a$ & $9.04 a$ \\
\hline LSD at 0.05 & 0.01 & 0.01 & 0.001 & 0.001 & 0.01 & 0.02 & 0.09 & 0.09 \\
\hline \multicolumn{9}{|c|}{ Interaction } \\
\hline $\mathrm{H} \times \mathrm{S}$ & ns & ns & * & * & * & * & ns & ns \\
\hline $\mathrm{H} \times \mathrm{N}$ & * & ns & * & * & * & * & * & ns \\
\hline $\mathrm{S} \times \mathrm{N}$ & * & ns & * & * & * & * & * & ns \\
\hline $\mathrm{H} \times \mathrm{S} \times \mathrm{N}$ & * & * & * & * & ns & * & * & * \\
\hline
\end{tabular}

Means at the same column followed by the same letter are statistically equaled according to L.S.D. at 0.05 value, ns: not significant and *: significant difference at 0.05 level of probability.

\section{CONCLUSIONS}

Considering the obtained results, it can be concluded that application of $384 \mathrm{~kg} \mathrm{~N} \mathrm{ha}^{-1}$ and with wider spacing $(40 \mathrm{~cm})$ between plants to the maize hybrid ' $30 \mathrm{~N} 11$ ' is an optimal for obtaining higher grain yield of maize under the agro-metrological conditions of Alexandria, Egypt.

\section{REFERENCES}

A.O.A.C. (1990). Official Methods of Analysis of Association of Official Analytical Chemists, $12^{\text {th }}$ edition. Washington, D.C.

Abdul, A., H. Rehman and N. Khan (2007). Maize cultivar response to population density and planting date for grain and biomass yield. Sarhad J Agric 23: 25-30.

Ahmad, M., A. Khaliq, R. Ahmad and A. M. Ranjha (2010). Allometery and productivity of autumn planted maize hybrids under narrow row spacing. Int. J. Agric. Biol., 12: 661-667.

Amin, Amal, Z. H. A. Khalil and R. K. Hassan (2003). Correlation studies and relative importance of some plant characters and grain yield in maize single crosses. Arab. Univ. J. Agric.Sci. Ain. Shams Univ. Cario 11(1):181-190.

Atia, A. A.M. and M.E. M. Abd El- Azeem (2005). Correlation, plath coefficient and regression analysis to determine the relative conttributions of some 
gronomictrils with grain yield in the maize (Zea mays L.) genotypes J. Agric. Sci. Mansoura Univ., 30(11):6503-6510.

Chapman, H. D. and P.F. Pratt (1978). Method of Analysis for Soil and Water. $2^{\text {nd }}$ Ed., Chapter, 17pp 150-161. Uni. Calif. Div. Agric. Sci. USA.

CoStat, 6.311, copyright (c). (2005). Cohort software798 light house Ave. PMB320, Monterey, CA93940 and USA. Email: info@cohort.com and Website: http://www.cohort.com/DownloadCoStatPart2.html.

Dawadi, D. R. and. S. K. Sah (2012). Growth and yield of hybrid maize (Zea mays, L.) in relation to planting density and nitrogen levels during winter season in Nepal. Trop. Agri. Res., 23 (3): $218-227$.

El-Gizawy, N. Kh. B. and H. M. Salem (2010). Influence of nitrogen sources on yield and its components of some maize varieties. World J. Agric. Sci., 6 (2): 218-223.

Faheed, Fayza A., E.I. Mohamed and Huda M. Mahmoud (2016). Improvement of maize crop yield (Zea mays L.) by using of nitrogen fertilization and foliar spray of some activators. J. Eco. Heal. Env., 4(1):33-47.

Gerpacio, V. R. and P. L. Pingali (2007). Tropical and subtropical maize in Asia: production systems, constraints and research priorities. CIMMYT, Mexico, ISBN: 978-970-648-155-9. p. 93.

Gomez, A. K. and A. A. Gomez (1984). Statistical procedures for agricultural research. ( $2^{\text {nd }}$ edition). John Wiley and Sons. New York.

Gustavo, A.M., G.C. Alfredo and M. E. Otegui (2006). Row width and maize grain yield. Agron. J., 98: 1532-1543.

Hasanuzzaman, M., M. L. Rahman, T. S. Roy, J.U. Ahmed and A.S.M. Zobaer (2009). Plant characters, yield components and yield of late transplanted aman rice as affected by plant spacing and number of seedling per hill. Advances in Biol. Res., 3(5-6): 201-207.

Hoshang, R. (2012). Effect of plant density and nitrogen rates on morphological characteristics grain maize. J. Basic. Appl. Sci. Res., 2(5): 4680-4683.

Jackson, M.L. (1973). Soil chemical analysis, Prentice Hall of India private limited, New Delhi, P. 498.

Johnson, L. F. (2001). Nitrogen influence on fresh-leaf NIR spectra. Remote Sens. Environ., 78:314-320.

Kandil, E. E. (2014). Determine independent population density for each maize hybrid (Zea mays, L.).Inter. Proc. Chemi. Biol. \& Enviro., 79 (6): 30 -35. 2nd Inter. Conf. on Agric. and Biotech., IPCBEE, IACSIT Press, Singapore, 27- 28 Dec. in Thailand.

Kandil, E. E. E. (2013). Response of some maize hybrids (Zea mays L.) to different levels of nitrogenous fertilization. J. Appl. Sci. Resh., 9(3): 19021908

Kar, P.P., K.C. Barik, P.K. Mahapatra, L.M. Garnayak, B.S. Rath, D.K. Bastia and C.M. Khanda (2006). Effect of planting geometry and nitrogen on yield, economics and nitrogen uptake of sweet corn (Zea mays). Ind. J. Agron. 51 (1): 43-45.

Khan, N. W., N. K. ljaz and A. Khan (2012). Integration of nitrogen fertilizer and herbicides for efficient weed management in maize crop. Sarhad J. Agric., 28(3). 
Klute, A. (1986). Methods of soil analysis part 1,2 $2^{\text {nd }}$ ed., Agron. Monor G. ASA and SSSA, Medison, W.I.

Kumar, A. (2008). Productivity, economics and nitrogen- use efficiency of specialty corn (Zea mays) as influenced by planting density and nitrogen fertilization. Ind. J. Agron. 53 (4): 306-309.

Lowther, G.R. (1980). Using of a single $\mathrm{H}_{2} \mathrm{So}_{4}-\mathrm{H}_{2} \mathrm{O}_{2}$ digest for the analysis of Pinus radiate needles. Commun.Soil Sci. pl.Analysis, 11: 175-188

Lyocks, S. W. J., J. Tanimu, D. L. Zamani and O. D. Ayodeji (2013). Evaluation of the effects of intra-row spacing on the growth and yield of maize (Zea mays I.) in maize-ginger intercrop in samaru, northern Guinea savanna of Nigeria. Agric. Biol. J. N. Am., 4(3): 175-180.

Martin, M. E., L. C. Plourde, S. V. Ollinger, M. L. Smith, B. E. A. Mcneil (2008). Generalizable method for remote sensing of canopy nitrogen across a wide range of forest ecosystems. Remote Sens. Environ., 112: 3511-3519.

Melkonian, J.J., H.M. Van Es, A.T. DeGaetano and L. Joseph (2008). ADAPT-N: Adaptive nitrogen management for maize using highresolution climate data and model simulations. In: R. Kosla (Ed.). Proceedings of the $9^{\text {th }}$ Int. Conference on Precision Agric., July 20-23, Denver, CO (CD-ROM).

Moosavi, S. G.; M. J. Seghatoleslami and A. Moazeni (2012). Effect of planting date and plant density on morphological traits, LAI and forage corn (Sc. 370) yield in second cultivation. Int. Res. J. Appl. and Basic Sci., 3 (1): 57-63.

Moraditochaee, M., M. K. Motamed, E. Azarpour, R. K. Danesh and H. R. Bozorgi (2012). Effects of nitrogen fertilizer and plant density Management in corn farming. ARPN Journal of Agricultural and Biological Science, 7(2): 133-137.

Nemati, A. R. and R. S. Sharifi (2012). Effects of rates and nitrogen application timing on yield, agronomic characterstics and nitrogen use efficiency in corn. Intl J. Agric. Crop Sci., 4(9): 534-539.

Oktem, G.A and A. Oktem (2005). Effect of nitrogen and intra row spaces on Sweet corn (Zea mays sachharata sturt) ear characteristics. Asian J. PI. Sci., 4 (4): 361-364.

Page, A. L., R. H. Miller and D. R. Keeny (1982). Methods of soil analysis part 2 Amer. Soc. Agric. Inc. Madison W.19:595.

Peng, D. L., B. Zhang and L.Y. Liu (2012). Comparing spatiotemporal patterns in Eurasian FPAR derived from two NDVI-based methods. Int. J. Digit. Earth, 5: 283-298.

Peykarestan, B. and M. Seify (2012). Impact of sowing date on growth and yield attributes of pop corn grown under different densities. Int. Res. J. Appl. and Basic Sci., 3(1): 85-91.

Saadat, S. A., H. R. Miri and B. J. Haghighi (2010). Study effect of density on yield and yield components in corn hybrids. Proceeding of $11^{\text {th }}$ Iranian Crop Sci. Congress. pp. 2914-2917.

Sahoo, S. C. and P.K. Mahapatra (2004). Response of sweet corn (Zea mays) to nitrogen levels and plant population. Ind J. Agric. Sci., 74 (6): 337-338.

Shapiro, C. A. and C. S Wortmann (2006). Corn response to nitrogen rate, row spacing and plant density Eastern Nebraska. Agron. J., 98: 529-535. 
Tandon, H. (1995). Methods of Analysis of soil, plants, waters and ferilizer, p: 144. Fertilizers development and consultation organization, New Delhi, India.

Tang, J. H., Y. P. Wang, Y. M. Hu, C. L. Wang, G. W. Tian and Z. H. Liu(2015). Effect of low $\mathrm{N}$ - stress to $\mathrm{N}, \mathrm{P}, \mathrm{K}$ contents and quantitative trait locus (QTL) analysis in maize kernels and stalks. Afr. J. Agric. Res. 10(27): 2633-2641.

Trenton, F., S. Stanger and G. L. Joseph (2006). Optimum plant population of Bacillus thuringiensis and non Bacillus thuringiensis corn in Wisconsin. Agron. J., 98: 914-921.

الملخص العربي

استجابة بعض هجن الذرة الثامية للتوزيع الفراغي ومعدلات التسميد التتيروجيني

محمود عبد العزيز جمعة فتحي إبراهيم رضوان عصام إسماعيل قنديل محمد عبد الله أمحمد حسين

قسم الانتاج النباتي - كلية الزراعة سابا باثا - جامعة الاسكندرية - الاسكندرية - مصر مرئ

أجريت تجربتان حقليتان بالمزرعة البحثية بكلية الزارعة سابا باثنا بمنطقة أبيس جامعة الإسكندرية خلال الموسمين

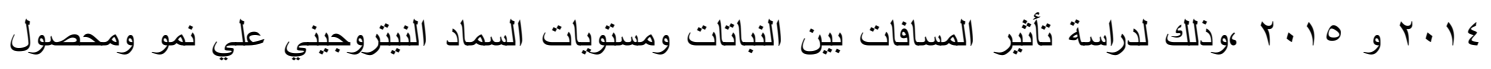
بعض هجن الذرة الثنامية. وإستخدام في تصميم القطع المنشقة مرنين في ثلاث مكررات في تتفيذ التجربتان ، حيث

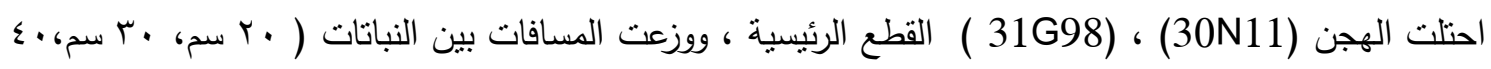

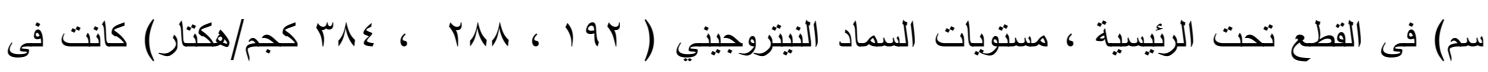
القطع تحت تحت الرئيسية. ولخصت أهم النتائج فيما يلي:

- تقوق هجين الذرة الثامية130N11 علي الهجين 31 معنو معنياً في معظم الصفات الددروسة في كلا الموسمين.

- زراعة النباتات علي مسافة • عسم حققت أعلى قيم للصفات تحت الدراسة ، بينما المسافة . r سم بين نباتات الذرة الثامية أدت لأقل قيم بالنسبة لارتفاع النبات ولصفات المحصول ومكوناته في موسمي الزراعة.

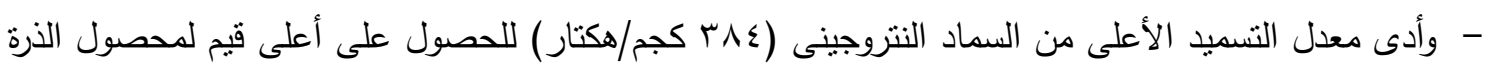

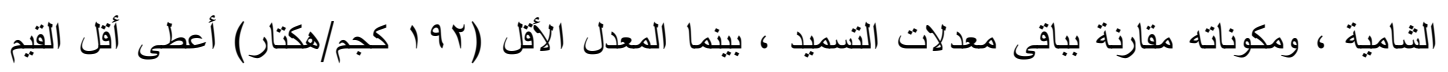
لهذه الصفات خلال موسمى الدراسة.

- أدى زراعة هجين 30N11علي مسافة • ــ سم بين النباتات الذرة الثامية للحصول على أعلى القيم للصفات

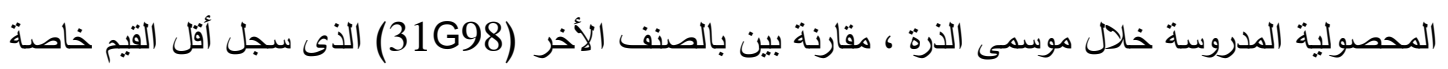
مع مسافة زراعة . r سم بين النباتات. - سجل الهجين 30N11 أعلى استجابة لمعدل التسميد النتروجينى عیب كجم/هكتار حيث حقق أعلى قيم لمحصول الحبوب والقش والمحصول البيولوجى خلال موسمى الزراعة. 


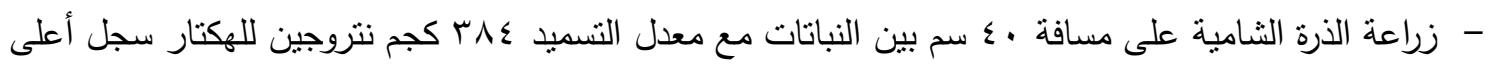

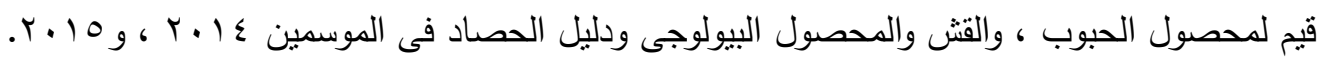

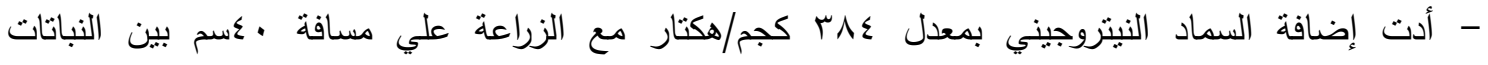
للهجينN11 إلي الحصول علي أعلي القيم للمحصول (محصول الحبوب، والقش البيولوجي (طن/هكتار) وأيضاً دليل الحصاد (\%) في كلا الموسمين. 